\title{
Ultrastructural Modifications of the Cavities Formed by Folliculostellate Cells in Chicken Adenohypophysis under Septic Shock Conditions
}

\author{
A.J. Fernández, ${ }^{*}$ M.A.Sierra, ${ }^{*}$ A. Méndez, ${ }^{*}$ E. Mozos, ${ }^{* *}$ Ma.C. Moyano, ${ }^{*}$ \\ and L. Carrasco* \\ * Departamento de Histología y Anatomía Patológica. Facultad de Veterinaria. \\ Universidad de Córdoba. España. \\ **Departamento de Histología y Anatomía Patológica. Facultad de Veterinaria. \\ Universidad de Extremadura. Cáceres. España
}

\begin{abstract}
Effects of septic shock by repeated inoculations with Escherichia coli on the ultrastructure of the folliculo-stellate cells and cavities of the adenohypophysis of the chicken were investigated in order to determine the function of these cavities.

The principal morphological modifications were dilation of the Golgi apparatus, endoplasmic reticulum and autophagic vacuoles, and necrosis phenomena in the stellate cells. The follicular cavities showed dilation, and there was heterogeneous dense material and granular elements in the follicular lumen. Based on results reported in the literature, the observations reported here are evidence of a "cleaning-role", for the removal of cell debris, when there is endocrine disfunction.
\end{abstract}

The fine structure of the chicken adenohypophysis has a cell type described as a chromophobic cell that appears in electron microscopy as secretory cells (2). In chickens these cells are morphologically similar to those found in mammals, sometimes appearing as clusters around a common central occluded lumen into which some microvilli project (1). In vertebrate pars distalis, chromophobic cells have a similar appearance and are known as "stellate-cells", "follicular-stellar" cells or, less frequently, as "follicular cells". Several functions have been attributed to these cells $(6,8,10)$. We here report on modifications of these cells induced by endocrine disfunction.

\section{MATERIALS AND METHODS}

Fifty 30-day-old male, white Legorn chickens that were free of infection and parasitic diseases were divided into five groups of 10 chickens. In each group, seven chickens were inoculated with $1.5 \mathrm{ml}$ doses Escherichia coli and three were as controls. Group I received one inoculation, group II two inoculations, group III three, group IV four, and group V five. Inoculations were done at $24 \mathrm{~h}$ intervals. The chickens were killed $24 \mathrm{~h}$ after the last inoculation.

The birds were decapitated, and samples of hypophysis collected immediately from each one. These samples were fixed first in $2 \%$ glutaraldehyde then in $2 \% \mathrm{OsO} 4$, after which 
they were dehydrated in acetone and embedded in epon-araldite. Sections of $40 \mathrm{~nm}$ were cut with an LKB III ultramicrotome, then stained with uranyl acetate and lead citrate. The stained sections were observed and photographed in a T.E.M. Jeol model $200 \mathrm{CX}$ electron microscope.

\section{RESULTS}

In groups I and II the follicular cavities showed low dilation and had heterogeneous dense material. Stellate cells were distributed throughout the gland with scanty cytoplasm around the nucleus, several slender processes extended between granulated cells throughout the parenchyma. The cavity was enclosed by stellate cells that were joined by occluding junctions and which displayed some projecting microvilli. A remarkable cytoplasm containing autophagic vacuoles was present in many of the folliculo-stellate cells in these groups (Fig. 1).

In groups III and IV, modifications in the cavities were represented by a great dilation with heterogenous strong dense material (Fig. 2). Granular elements and necrosis processes appeared in some follicular cells (Fig. 3).

Important ultrastructural cell changes were observed in folliculo-stellate cells after three and four inoculations. These cells had numerous lysosomes and showed dilation of the saccules in the Golgi aparatus and endoplasmic reticulum. Moreover, large vacuoles (digestive vacuoles) occupied part of the cytoplasm.

In group $\mathrm{V}$, the follicular cavities showed low dilation and had heterogenous dense material and granular elements (Fig. 4). Cells were linked by maculae and zonulae adherens near the abluminal surface. In this group, as in III and IV, necrosis was present in some follicular cells, and intracellular autophagic vacuoles.

Mitosis was frequent in the follicular cells of all the groups.

\section{DISCUSSION}

Cells of chicken stellate cavities are morphologically similar to those of other species $(3,5,6,7)$. They do not contain secretory granules, but have thin cytoplasmic proyections that extend among the granulated cells $(1,2,3)$, and microfilaments in their cytoplasms. They are also linked by junction complexes and they surround cavities filled with heterogeneous material into which microvilli protrude $(1,3,5)$.

Efforts to relate the structure and function of nongranulated cells have produced contradictory conclusions: they have been associated with the production of ACTH (3), but this idea is not supported by immunocytochemical findings at the ultrastructural level; they have been related to the transfer of waste material; from degenerating cells and during endocrine disfunction by phagocytosis, which is substantiated by the presence of lysosomes and autophagic vacuoles in non-granulated cells $(8,10)$; they have been associated with mechanical support within the hypo-

Fig. 1. Low dilation of the lumen of a follicular cavity and of folliculo-stellate cells (Arrow: lysosome). $\times 8,500$

Fig. 2. Follicular cavity with heterogeneous dense material and mitosis in adenohypophysis parenchyma cells. $\times 6,000$

Fig. 3. Necrosis of folliculo-stellate cells in one follicular cavity from group $4 . \times 7,500$

Fig. 4. Dilated cavity with granular elements and heterogeneous dense material present in both groups 4 and $5 . \times 14,000$ 


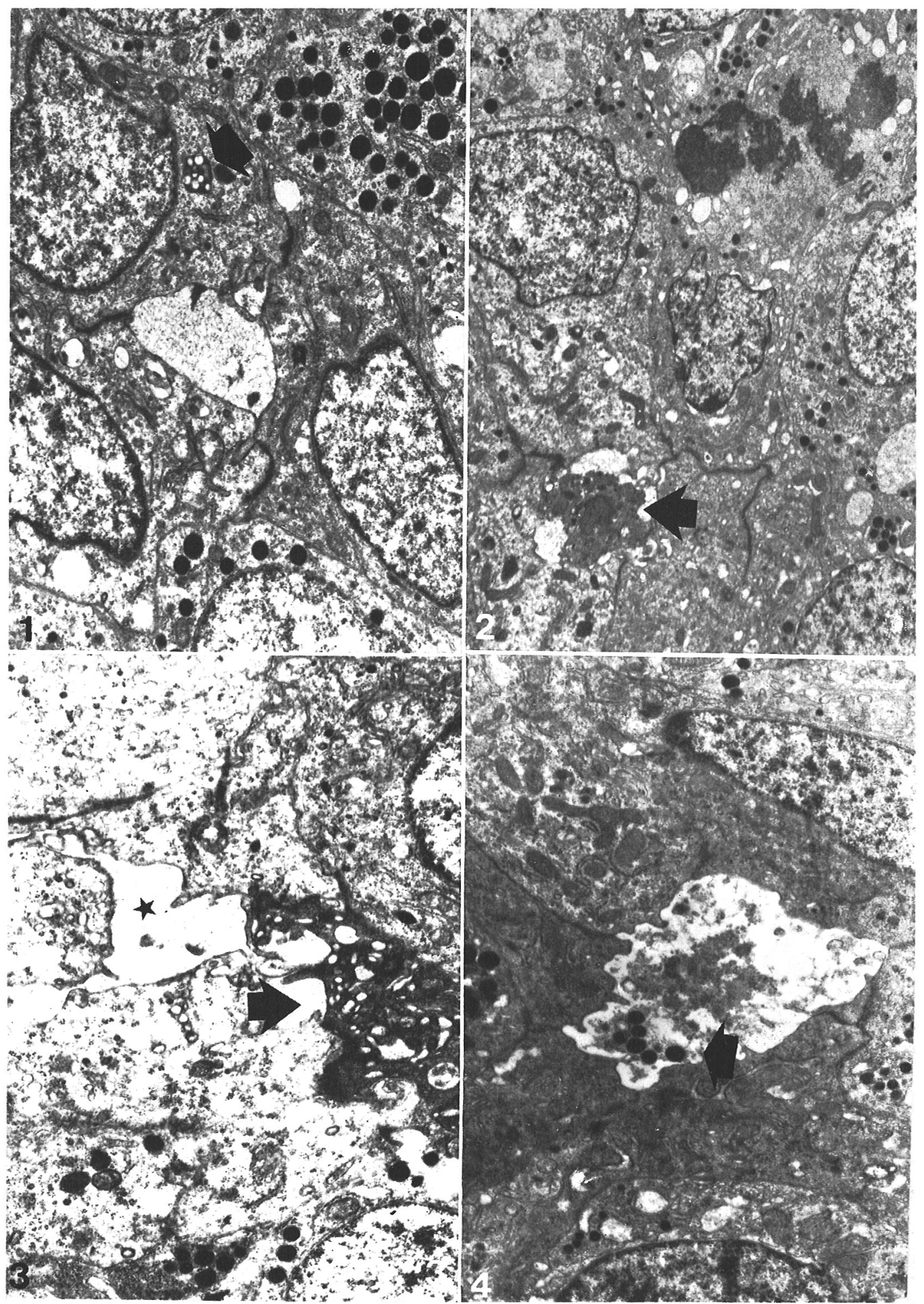


physis (1); also Vila-Porcile (10) has proposed a role in the transport of cell debris or substances to the blood stream or in trophic functions; and these folliculo-stellate cells have been seen as embryonic residues or undifferentiated cells that might differentiate into secretory cells (4).

The ultrastructural modifications found in our experiments show that folliculostellate cells and follicular cavities function in the septic shock induced in chickens by Escherichia coli.

Our second experimental group showed dilation of follicular cavities that were filled with heterogeneous dense material; but this phenomenon was more evident in groups 3 through 5, in particular in group 4 in which granules were shown secreted in the lumen. These modifications $(6,7)$ were possible due to adenohypophysis hyperfunctioning during the shock process; therefore, the follicular cavities functioned for storage (9) and cleaning (10).

Follicular cells that had autophagic vacuoles $(8,10)$ confirmed a phagocytic role for these cells in hyperfunctioning adenohypophysis. Mitosis of the follicular cells accounts for a substitution mechanism for necrotic cells (10), which occurs in stress and shock caused by different agents $(6,10)$.

We conclude that morphological changes in the follicular cavities and in folliculostellate cells are evidence that these structures have a cleaning function and provide a storage place for cell debris.

\section{REFERENCES}

1. Blanco, A., F. Gracia-Navarro and A. Jover. Ultrastructura de celulas y cavidades foliculares en adenohipofisis de sapo (Bufo bufo). Archv. Zootec. 27, 207-215, 1978

2. Doer-Shotт, J. Etude comparative de la cytologie et $\mathrm{l}^{\prime}$ ultrastructure de l'hypophyse de trois espèces d' amphibiens Anoures Rana temporaria L. Bufo vulgaris L. Senopus laevis D. Gen. Comp. End. 5, 631-653, 1965

3. FARQuhar, M.G. "Corticotrophs" of the adenohypophysis as related by electron microscopy. Anat. Rec. 7, 127-291, 1957

4. Girod, C. and M. Lheritier. Ultrastructure des cellules folliculostellaires de la pars ditalis de $\mathrm{l}^{\prime}$ hypophyse chez le spermophile (Citelus variegatus Erxeleben), le graphiure (Graphiurus murinus), et le herison (Erinaceus europeaus linnaurus). Gen. Comp. End. 43, 105-122, 1981

5. Gracia-Navarro, F., J.A. Gonzalez-Reyes, F. Guerra-Callejas and G. Garcia-Herdugo. An electron microscopy study of stellate and cavities in the pars distalis of frog pituitary. Cell Tiss. Res. 15, 729-736, 1983

6. Harrison, F., J. Hoof Van and L. VakaET. The relationship between the folliculo-stellate network and thyrotropic cells of the avian adenohypophysis. Cell. Tiss. Res. 226, 97-111, 1982

7. Harrison, F., J. Hoof Van and L. VaKaet. Processing of cell debris suggestive of phagocytosis in the follicular cavities of avian adenohypophysis. Cell. Biol. Int. Reports. 6, 153-161, 1982

8. Perryman, E.K., J. De Villes and J.T. Bagnara. Phagocytic activity of the stellate cells in the anuran pars intermedia. Cell. Tiss. Res. 208, 85-98, 1980

9. Shiotani, Y. An electron microscopy study on stellate cells in the rabbit adenohypophysis under various endocrine conditions. Cell. Tiss. Res. 213, 237-246, 1980

10. Vila-Porcile, E. La pars distalis de l'hypophyse chez le rat. Contribution à son étude histologique et cytologique en microscopie électronique. Ann. Sci. Nat. Zool. 12, 61-98, 1973 